\title{
Transverse incision in radical neck dissection
}

\author{
Incisión cervical transversa en disección radical de cuello
}

José Francisco Gallegos-Hernández*

Department of Head and Neck Tumors, Oncology Hospital, Centro Médico Nacional Siglo XXI, IMSS, Mexico City, Mexico

\begin{abstract}
Background: Radical neck dissection is the only way to stage patients with neoplasms at risk of lymph node metastases; various types of incisions have been made throughout history, the goal: to obtain sufficient exposure to allow complete resection of the nodal groups at risk. It is important to combine oncological safety with adequate aesthetics, functionality and quality of life. Methods: Retrospective evaluation of the result obtained with the transverse neck incision in patients submitted to radical neck dissection, the parameter used to know if this incision is adequate is the number of dissected lymph nodes. Results: There are 35 patients, 30 with metastasis of squamous cell carcinoma and 5 with melanoma metastasis. The average of dissected lymph nodes was 25. A single incision allowed the dissection of the five nodal levels, it was not necessary to convert the incision or make vertical enlargements; the cosmetic result was satisfactory in all patients, there were no major complications. Conclusion: The unique transverse cervical incision allows access to the five cervical levels, it can be enlarged bilaterally; in the present series, the mean number of dissected lymph nodes was 25 enough to consider the procedure as complete. The aesthetic result was satisfactory.
\end{abstract}

KEY WORDS: Neck dissection. Transverse incision. Radical neck dissection. Node metastasis.

\section{Resumen}

Antecedentes: La disección radical de cuello es la única forma de estadificar a pacientes con neoplasias con riesgo de metástasis ganglionares. Se han efectuado diversos tipos de incisiones a lo largo de la historia, con el objetivo de obtener una exposición suficiente que permita la resección completa de los grupos ganglionares en riesgo. Es importante combinar la seguridad oncológica con unas adecuadas estética, funcionalidad y calidad de vida. Método: Evaluación retrospectiva del resultado obtenido con la incisión transversa en el cuello en pacientes sometidos a disección radical. El parámetro utilizado para saber si esta incisión es adecuada es el número de ganglios disecados. Resultados: Son 35 pacientes, 30 con metástasis de carcinoma epidermoide y 5 con metástasis de melanoma. La media de ganglios disecados fue de 25. Una sola incisión permitió la disección de los cinco niveles ganglionares; no se requirió convertir la incisión ni hacer ampliaciones verticales. El resultado cosmético fue satisfactorio en todos los pacientes, y no hubo complicaciones mayores. Conclusión: La incisión cervical única transversa permite el acceso a los cinco niveles cervicales y puede ser ampliada bilateralmente. En la presente serie, la media de ganglios disecados fue de 25 , número suficiente para considerar al procedimiento completo. El resultado estético fue satisfactorio.

PALABRAS CLAVE: Disección de cuello. Incisión transversa. Disección radical de cuello. Metástasis ganglionares.

\author{
Correspondence: \\ *José Francisco Gallegos-Hernández \\ Av. Cuauhtémoc, 330 \\ Col. Doctores \\ C.P. 06725, Ciudad de México, México \\ E-mail: gal61@ prodigy.net.mx
}

Date of reception: 08-12-2017

Date of acceptance: 14-05-2018

DOI: 10.24875/CIRUE.M18000045
Cir Cir. 2018;86:268-272

Contents available at PubMed www.cirugiaycirujanos.com 


\section{Introduction}

Cervical incisions for the performance of radical neck dissection have undergone modifications over time since the procedure was described by George Crile $^{1}$ and popularized by Hayes Martin and his team².

The purpose of radical neck dissection is to achieve an adequate staging of patients with cancer originating in the upper aerodigestive tract or in the thyroid gland, and with any neoplasm at risk of occult lymph node metastases or clinically present at diagnosis. The neck incision, which is a route through which different cervical lymph node levels are accessed, is essential to achieve the removal of all at-risk or compromised lymph nodes, and to avoid leaving metastatic adenopathies that might imply neoplastic recurrence.

Radical neck dissection itself has undergone changes both in extent and radicalness over time; currently, there is enough evidence for selective procedures to be carried out according to tumor site and cervical lymph node staging ${ }^{3}$. Classical radical dissection, as described by Crile in $1906^{1}$, is currently performed in approximately $10 \%$ of patients with upper aerodigestive tract cancer, since the modifications that prevent resecting non-lymph node structures (sternocleidomastoid muscle, internal jugular vein and spinal accessory nerve) offer the same oncological control and have considerably decreased the morbidity the procedure implied. The relationship between oncological effectiveness and quality of life is now more important than ever, and an approach focused on esthetics and functionality, while being effective from the oncological point of view, is therefore required ${ }^{4}$.

Facial dissection (in which en bloc resection of the entire lymph node chain together with the jugulocarotid fascia is performed and that prevents isolated lymph node removal) is essential for achieving an adequate dissection of at-risk or metastatic lymphnode levels, and further decreases complications and drainage times ${ }^{5}$.

According to the above, it is essential offering an incision that allows complete dissection, with minimal morbidity and with an esthetic and functional satisfactory result.

Single transverse cervical incision allows leaving minimal trace in the neck and access all five lymph node levels, avoiding esthetic and functional sequelae

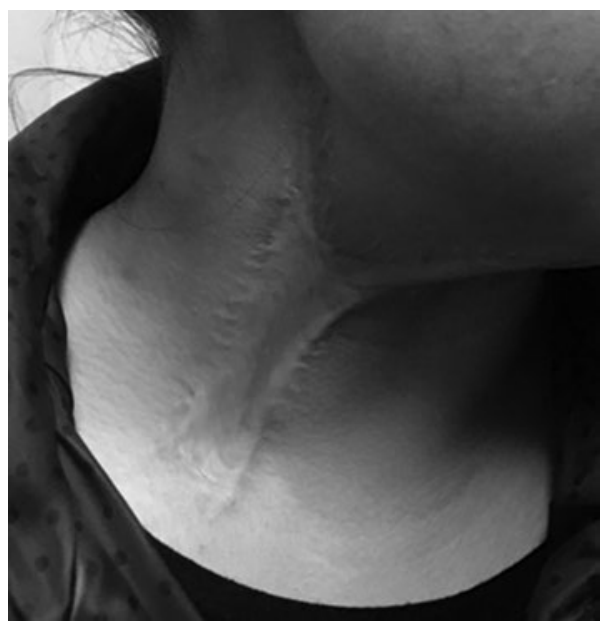

Figure 1. Vertical incisions, against Langer lines of expression, increase cervical contracture, produce a keloid scarring, decrease neck mobility and give rise to chronic cervical pain.

as other types of incisions do, especially those that combine vertical and horizontal incisions (Sibeleau-Carreaga) (Fig. 1).

The purpose of this article is to show our experience with this type of incision in patients undergoing radical neck dissection for neoplasms originating in different sites in the head and neck area. The parameter used to consider it to be effective is the dissection of all cervical levels and the number of dissected lymph nodes.

\section{Method}

Retrospective analysis of medical records of patients undergoing radical neck dissection via unilateral or bilateral single transverse cervical incision.

The incision in all patients was carried out following the middle cervical skin fold with vertices on the trapezium front border and the midline of the neck at the level of the thyroid notch (Fig. 2).

When level IA dissection was required, the incision was prolonged $2-3 \mathrm{~cm}$ towards the other side of the neck (extended transverse incision); when performing a bilateral neck dissection was required, this incision was prolonged up to the anterior border of the contralateral trapezius muscle (bilateral transverse incision).

All levels were identified with specific markers at the time of surgery and were thus referred, forming a single block (facial dissection), to pathology (Fig. 3).

The number of dissected lymph nodes was assessed in the pathology report, with a dissection being considered complete if at least 25 lymph nodes were resected. 


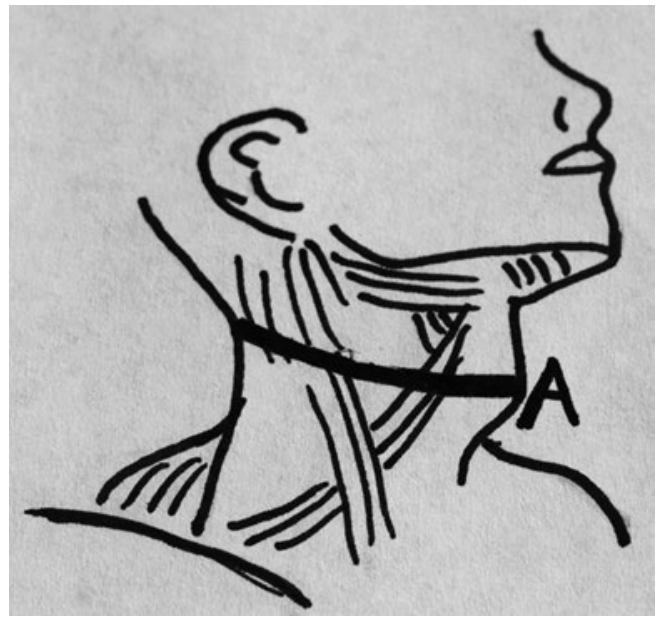

Figure 2. Single transverse cervical incision $(A)$ has its vertices on the midline of the neck at the level of the thyroid notch and on the anterior border of the trapezium muscle, following the transverse cervical skin fold. The flaps are subplatysmal, both superiorly (up to the mandibular border) and inferiorly (up to the collarbone).

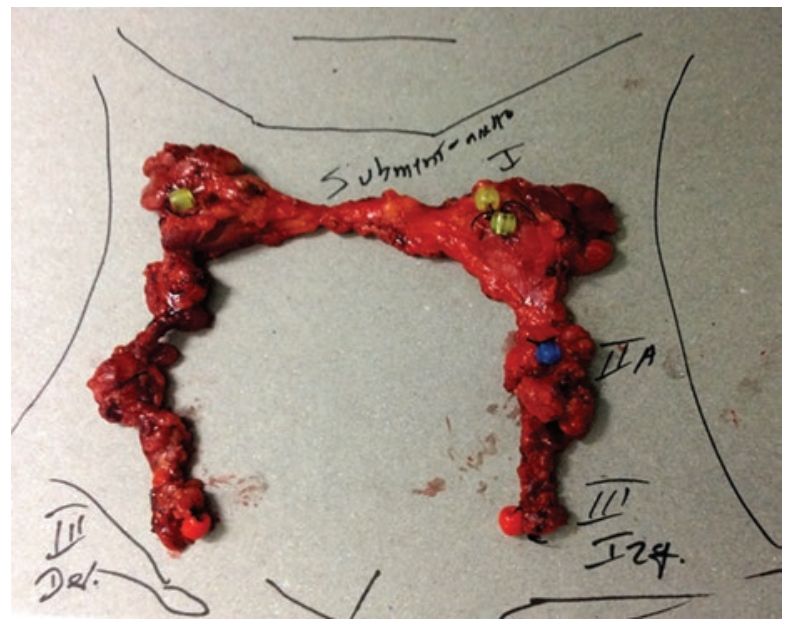

Figure 3. Facial cervical dissection allows neck lymph nodes en bloc resection including the vascular fascia, prevents at-risk lymph nodes from being left in the patient and offers an adequate lymph node density index (dissected/metastatic lymph nodes ratio).

A closed drainage was placed in all patients at the end of the intervention; the number of drains depended on each patient's neck characteristics and on the extent of dissection.

The wound was sutured in two planes (platysma and skin). Patients who had undergone reconstruction with free or pediculated flaps were not included.

In none of them was isolated lymph node dissection, adenectomy or tumorectomy performed.

\section{Results}

Thirty-five patients were included, 20 men and 15 women, with an average age of 52 years. Among
Table 1. Primary tumor sites of origin

\begin{tabular}{lc}
\hline Primary tumor site & $\mathbf{N}(\%)$ \\
\hline External ear melanoma & $2(5.7)$ \\
Melanoma of the face & $2(5.7)$ \\
Scalp melanoma & $1(2.8)$ \\
Oral cavity carcinoma & $17(48.5)$ \\
Oropharyngeal carcinoma & $8(22.8)$ \\
Metastasis with unknown primary & $5(14.2)$ \\
Total & $35(100)$ \\
\hline
\end{tabular}

them, 30 had been diagnosed with squamous cell carcinoma metastases originating in mucous membranes of the head and neck area, and 5 had been diagnosed with cutaneous melanoma originating in the cervical-facial skin.

Table 1 shows the origin of the primary tumors.

Most patients (15) underwent anterolateral neck dissection, which comprises levels I to IV; in 11 patients, the dissection was complete, with dissection of levels I to $\mathrm{V}$ being carried out; and in 9 patients, dissection was from levels I to III or supraomohyoid. In all patients was level IIB or retrospinal recess dissection included.

In 25 patients, the dissection was elective (no palpable lymph nodes) and in 10 it was therapeutic, with palpable metastases or visible metastases on ultrasound. The procedure was carried out as rescue (after radiotherapy failure) in 6 patients, and in 29 it was performed as first-line treatment.

Mean dissected lymph nodes were 32. The type of dissection that fewer lymph nodes obtained was the supraomohyoid dissection, with a mean of 25 . No patient had a dissection of less than 20 lymph nodes.

As for post-dissection sequelae, four patients had facial nerve inferior branch paresis (11\%), which was temporary in three and permanent in one. Two patients had sequelae of the XI cranial nerve; in both, the sequel was definitive and was associated metastasis at level IIB.

No patient had major complications or had to be re-operated. There was also no flap necrosis, wound dehiscence or cervical sepsis.

\section{Discussion}

Radical neck dissection is the standard surgical procedure to for achieving an appropriate staging of patients with lymph node metastases to the neck or 


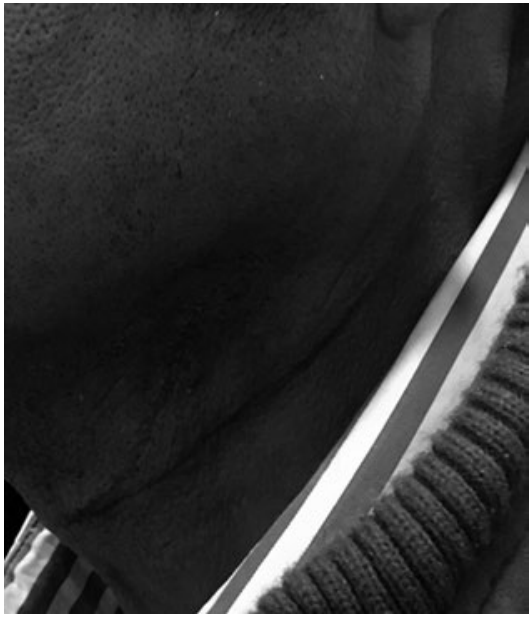

Figure 4. Single transverse cervical incision offers a satisfactory esthetic effect on the long term and achieves a balance between quality of life and oncological safety.

who are at risk of metastases not yet detected by clinical or imaging examination ${ }^{3,6}$.

The objectives pursued by radical neck dissection are staging, patient classification in risk groups, avoiding cervical recurrences that cannot undergo rescue procedures subsequently, and achieving regional control of a neoplasm ${ }^{7}$.

To be effective and meet its purposes, the procedure needs adequate exposure of the surgical field in order to achieve the dissection of all lymph node levels of the neck, it has to allow cervical flaps irrigation to prevent their ischemia, and requires an adequate relationship of the incision with the vessels of the neck in order to limit their exposure in case of wound dehiscence; it should also offer the possibility to include the site of the primary lesion in the resection if necessary, be compatible with reconstructive procedures, allow adequate separation of stomas (mainly tracheotomy) and provide an adequate cervical function with a good cosmetic-esthetic result ${ }^{7}$.

Approaches that combine horizontal with vertical incisions not only compromise esthetics and the function of the neck, but are also likely to produce contractures and keloid scars, and deteriorate patient quality of life. The most commonly used for this approach is the Sibeleau-Carreaga-type or " $Y$ " incision; the intersection of the horizontal with the vertical portion usually remains in the carotid bulb, so that any wound complication can involve vascular axis exposure with the ensuing risk. Double horizontal incisions of the McFee type compromise flap irrigation, especially of the intermediate dermal bridge. The Paul André-type incision, or "hockey stick" or "J" incision has a vertical portion that opposes the Langer lines and facilitates the generation of keloids or contractures $^{8}$. Evidently, all of them offer adequate surgical exposure of all cervical levels and facilitate facial dissection of the neck.

All the aforementioned cervical incisions, if accompanied by a facial-type lymph node dissection, allow accessing all five cervical levels and obtaining 20 or more lymph nodes in the specimen; however, all different esthetic and/or functional complications due to flap necrosis or eventual exposure of the vascular axis, are more significant than with single transverse incision ${ }^{9}$.

It is necessary for a balance between an appropriate approach from the oncological point of view, esthetics and function to be achieved, with minimal sequelae and complications ${ }^{10,11}$.

The ratio between dissected and metastatic lymph nodes, or "lymph node density index" is a prognostic factor with independent value in patients with head and neck cancer. It is very important that during radical neck dissection the procedure is carried out in the form of facial dissection to obtain the largest number of dissected lymph nodes and decrease the possibility of regional recurrence; the lower the number of dissected lymph nodes and the larger the number of metastatic lymph nodes, the worse the patient prognosis ${ }^{11}$. In the present series, transverse incision allowed achieving a satisfactory number of dissected lymph nodes, and it can therefore be considered as a safe approach from the oncological point of view.

Transverse cervical incision offers a satisfactory combination between lymph node dissection (in dissected lymph node and cervical level numbers) and adequate esthetic result (Fig. 4), allows an approach at all levels of the neck and offers, even in patients with a history of radiotherapy, minimal risk of flap necrosis. It can be used bilaterally both for supraomohyoid dissection and unilateral or bilateral complete dissection.

\section{Acknowledgments}

To Natalie Gallegos Garcia, artist, for her contribution with the drawing of the transverse cervical incision.

\section{References}

1. Crile G. Excision of cancer of the head and neck, with special reference to the plan of dissection based on 132 patients. JAMA.1906; 47:1780-6.

2. Martin H, Del Valle B, Ehrlich H, Cahan WG. Neck dissection. Cancer. $1951 ; 4: 441-9$. 
3. Gallegos-Hernández JF, Martínez-Gómez H, Flores-Díaz R. La disección radical de cuello en el cáncer de vías aero-digestivas superiores (VADS). Indicaciones, extensión y radicalidad. Cir Cir. 2002;70:369-76.

4. Song CM, Ji YB, Kim IS, Lee JY, Kim DS, Tae K. Low transverse incision for lateral neck dissection in patients with papillary thyroid cancer: improved cosmesis. World J Surg Oncol. 2017;15:97.

5. Durán-Briones G, Gallegos-Hernández JF, Rendón-Arroyo ME, Hernández-Hernández DM. Tiempo de drenaje en pacientes sometidos a disección radical de cuello. La influencia de la perfusión de líquidos en el periodo peri-operatorio. Gac Med Mex. 2011;147:5-11.

6. Paleri V, Urbano TG, Mehanna H, Repanos C, Lancaster J, Roques T, et al. Management of neck metastases in head and neck cancer: United Kingdom National Multidisciplinary Gidelines. J Laryngol Otol. 2016;130:S161-9.

7. Chagas JF, Pascoal MB, Aquino JL, Brandi LA, Previtale EV, Trillo AS, et al. Single transverse extended incision for radical neck dissection. Rev Col Bras Cir. 2016;43:270-5.
8. Guillier D, Moris V, Al Hindi AA, Rem K, Chatel H, See LA, et al. Surgical approaches in neck dissection: comparing functional, oncologic and aesthetic aspects of transverse cervicotomy to Paul André's approach. Ann Chir Plast Esthet. 2018;63:140-7.

9. Magrin J, Kowalski LP, Correia LMC. Esvaziamentos cervicais. En: Kowalski LP, editor. Afecções cirúrgicas do pescoço. São Paulo: Atheneu; 2005. p. 183-99.

10. Gane EM, Michaleff ZA, Cottrell MA, McPhail SM, Hatton AL, Paniza BJ, et al. Prevalence, incidence and risk factors for shoulder and neck dysfunction after neck dissection: a systemic review. Eur J Surg Oncol. 2017;43:1199-218.

11. Kim RY, Ward BB, Brockhoff $\mathrm{HC} 2^{\text {nd }}$, Helman JI, Braun TM, Skouteris CA. Correlation of lymph node density with negative outcome predictors in oral and maxillofacial squamous cell carcinoma. J Oral Maxillofac Surg. 2016;74:2081-4. 